\title{
RISING FOOD PRICE AND ITS CONSEQUENCES
}

Hem Raj Regmi (Msc) ${ }^{19}$

\begin{abstract}
Agricultural prices have risen worldwide sharply in the last two years, which has been a dilemma especially to policy makers. Higher agricultural prices would improve farmer's income and their living standards as well as investment in agriculture provided a fair mechanism of income transfer to them be instituted. However, the price rise seriously affects urban poors' food affordability and thus their livelihood. Various types of natural disasters particularly floods, droughts and landsides have affected agricultural crop production in Nepal resulting in fluctuations in food supplies and prices. Besides, policy measures associated with crop production, food balance and trade, petroleum price stabilization and liquor production directly or indirectly affect food market and prices. National food production, demand-supply, consumption and price scenarios and associated reasons are analyzed based on reviews of pertinent literatures.
\end{abstract}

Key words: Food production, food consumption, demand-supply, price-scenario, Nepal

\section{INTRODUCTION}

The United Nations Organization has recently estimated that more than one billion population in the world is going to be poor in terms of per capita calorie consumption, simply because the peoples have to expend about $40 \%$ of income on the food items in their normal food basket. They are unable to pay but compelled to cut their daily ration. Non-poors are also compelled to spend more on food affecting their expenditure on none food essentials such as education, health, fuel, clothing and housing. One third of Nepalese people are poor in terms of daily calorie requirement (CBS, 2007), and are subject to victimize due to sudden price hike on food items.

A $6.4 \%$ change in urban consumer price index from Jan. 2007 to Jan. 2008 was observed

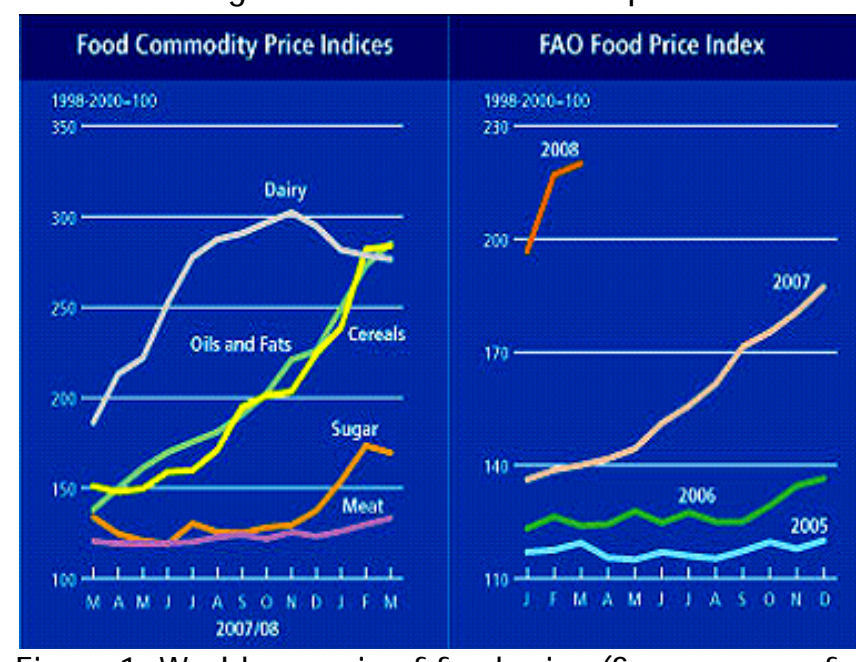
(Annex 1) with a highest price increase in oil and ghee followed by rice and pulses in order and a price decline in the items such as vegetable, spices and sugar. Comparative prices of food items for the month of Chaitra (March/ April according to Nepalese calender) in 2006 and 2007 showed highest increase in price of oils followed by lentil, milk and coarse rice. While the price of sugar and related products decreased by $10 \%$ Among the 26 items listed, the prices of 23 items have increased and that of the rest decreased (DOA, 2007).

Figure 1: World scenario of food price (Source: www.fao.org)

${ }^{19}$ Senior Statistician, MOAC, Email: hrregmi@moac.gov.np 
Recent global scenarios showed an increase in food price index, compounded based on meat, dairy, cereals, oils/ fats and sugar prices, from 140 points to 220 points in a year's period from Mar. 2007 to Mar. 2008 (fig. 1). It indicated that more and more people, particularly those who are poor and do not produce their food themselves, are mostly affected by the unexpected price rise in food items.

\section{NATIONAL FOOD CONSUMPTION SCENARIO}

Nepal Living Standard Survey showed that the share of food in total expenditure of average Nepali people is about 59 percent where as it is about 65 percent for those who are living

Share on below poverty line peoples'

exoenses bu food and nonfood items

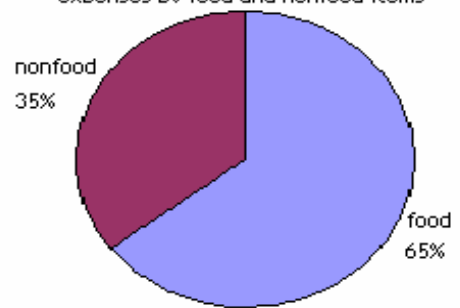

Share on average Nepalese people's expenses by food and nonfood items

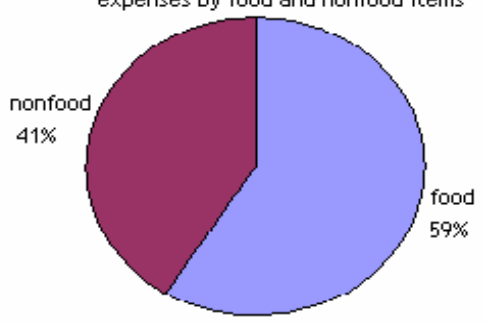

Figure 2: Food share on people's expenses below poverty line (CBS, 2005). The remaining share of expenditure is on nonfood items. The rising price would compel the households to expend more on food items affecting family health, education and housing adversely. Based on CBS (2005), the poverty line in 2003/04 prices would be at Nepalese Rs. 7696.00 with about an expenses of Rs. 5000.00 in food items. The alarmingly increasing food prices would certainly affect the poors as well as nonpoors just above the poverty line. Therefore, measures have to be taken in time against possible riots due to rising food prices in the days to come.

CBS (2005, p.61) has described 37 items in the Nepalese food basket, in which the highest share is of coarse-rice followed by fine rice, milk, wheat flour, potatoes, maize flour, maize and millet in order. These food items shared about 80 percent in the basket meaning that the price hikes in such items affected all of them who consumed the food items.

\section{NATIONAL FOOD DEMAND AND SUPPLY SCENARIO}

With almost $65 \%$ of agricultural land rain fed, annual agricultural output is highly dependent on weather conditions. For example, low monsoon in 2006/ 07 resulted in a decrease in paddy production by 600 thousand metric ton as compared to preceding year, thus contributing to a shortfall of about 200 thousand metric ton in the national food balance. The following year, the country had surplus food, as the monsoon was normal. The country's cereal production in f.y. 2007/ 08 was about 8 million metric tons, sharing the total in order by paddy (53\%), maize $(23 \%)$, wheat $(20 \%)$, millet $(<4 \%)$ and barley $(<1 \%)$. There had been a boost in paddy production from 1998 ( 3.6 million metric ton) to 2003 (4.45 million metric ton) with an average annual production of 4.2 million metric ton because of good weather conditions. However, a decline in paddy and barley production was observed in the later years mainly due to drought condition. Production of wheat and maize just maintained a positive growth, while that of millet remained constant around 290,000 metric ton.

Being self-sufficient until 1990, food grain production in Nepal fell short of population growth during the nineties. With a leap in cereal production in 1999, Nepal once again became selfsufficient in food grains. Due to drought, the production fell short by $23,168 \mathrm{mt}$. in 2005/ 06 and ever highest by $188000 \mathrm{mt}$. in 2006/07. The food balance varied across regions and ecological belts. The Eastern region including all ecological belts had a food surplus. 
Ecologically, the terai, where resided almost half of the country's population, is food surplus area as the granary of the country, while the hills and the mountains are food deficit belts (MOAC, 2007).
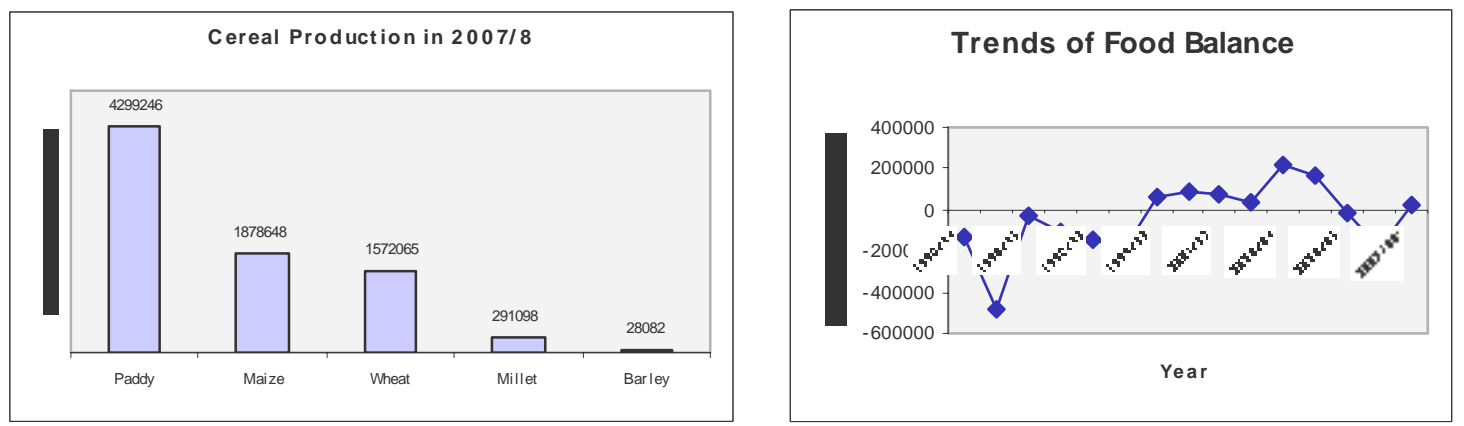

Figure 3: Cereal Food Production in Nepal,2007/ 08 (source: MOAC, 2007)

To offset shortage in national food balance, additional supplies through imports or food aids are essential. A deficit in the national supply triggers higher prices for food grains that in turn stimulates food imports especially by private sectors. Rice is primarily imported from India, which has accounted for 93 to 100\% of the total import during 1996/97 to 2003/04 period (DOA, 2007). There has been wide variation in cereal import from India ranging in values from NRs 16 million in 1998/99 to 277 million in 2000/2001. Average annual import of rice is around $75,000 \mathrm{mt}$., and that of wheat $4,700 \mathrm{mt}$. Nepal receives food aid through bilateral sources such as Japan and France, and multilateral sources such as United Nation's World Food Program (MOAC/WFP/FAO, 2007). The quantity of food aid varied from $1892 \mathrm{mt}$. in 1994 to $24299 \mathrm{mt}$. in 1999/ 00 with an average of $8000 \mathrm{mt}$.

\section{POSSIBLE REASONS OF RISING FOOD PRICES}

Several reasons have contributed to soaring food prices in Nepal. An expanding urban population, income growth and other consequences of high economic growths in China and India in the recent years have resulted in changes in consumers' preferences and habits of expenditure in the country as well. Global food demand is shifting from grains and other staples to processed and high-value food items such as vegetables, fruits and dairy- and meatproducts. Petroleum price hikes in the recent days have increased input costs in agriculture particularly due to fuel, fertilizers and transportation to increase food prices. Bio-fuels production as an alternative source of energy is also contributing to dramatic changes in the world's food balance, and especially corn-based ethanol production in the USA to reduce oil consumption, keep corn prices high for farmers there and to reduce carbon dioxide emissions is criticized for causing food shortages and food price rises in the developing world. In addition, changes in demand and supply of cereals in the world food market due to bio-fuels production could further increase cereal prices by 10-20\% benefiting net food exporter such as India, and net importers of cereals such as Nepal, China and almost all African countries and net buyers of food there would suffer from resulting high prices. Recent ban in India on export of none basmati-rice and wheat has induced food price hikes in Nepal and Bangladesh.

World agricultural output is projected to decrease significantly due to global warming, and its impact is expected to be much severe in developing countries. The major shock of which would primarily affect food supplies and prices and net food buyers' economy. 
Food prices had been steadily decreasing since the Green Revolution. However, the days of food price fall might be off set due to recent market globalization and interests of net food exporting countries. Surging demands for feed, food and fuel have recently led to drastic price increases, which are not likely to fall in the near future due to low stocks and slowgrowing supplies of agricultural outputs. Economic growth would help reduce hunger particularly if food distribution were equitable. Unfortunately, trickle down effects of economic growth rarely reach the poorest peoples.

Rapidly changing food habits in urban as well as rural areas has also been a cause of rise in food prices. For example, consumption of maize in rural areas has dramatically reduced. Instead, maize has rather been a cash crop as it is being supplied to feed industries. The increased poultry industries and high demand of them for feed has increased maize and soybean prices. Generally, farmers used to sell maize and purchase coarse-rice imported from India contributing to further rise in rice prices.

\section{CONCLUSION AND RECOMMENDATIONS}

Rising food prices have become the major concern of international communities as well as state government. Given the various risks and challenges posed by rapidly increasing food prices, current market trends and government policies could exacerbate hunger and poverty problems in poorer segments of people. Therefore, the time has come to formulate proper policies in its mitigation and implement them through appropriate instruments such as provision of subsidies on agricultural production inputs particularly seed, fertilizer, energy and finance and infrastructure development such as irrigation, road, electricity and market. A subsidized distribution of common food items through ration card to the urban poor would help to cope with the effects of rising food prices. Likewise, policy measures on early childhood nutrition focused on poorest households would be relevant from social justice point of view.

As the world food situation is being defined by new driving force such as income growth, climate change and increased production of bio fuels, global communities have to pay due attentions on human nutrition and health and agriculture development, and special attention on feeding of the world's poor and hungry peoples so that they would be streamlined into the development. Developed countries should respond to global food price rises by easing food transfer to importing countries and eliminating the programs that set aside food resources. And developing countries should increase investments on rural infrastructure and marketing development enhancing crop productivity. The policymakers should consider agriculture and food issues while formulating agenda on climate change, and the agendas should in particular relate to ensuring food security of poor peoples in developing countries since they are most vulnerable to the risks due to climate change.

\section{REFERENCES}

DOA, 2007. Agricultural marketing information bulletin (Special Issue-2007). Marketing Development Directorate, Department of Agriculture, Nepal.

CBS 2005. Poverty Trends in Nepal. In: Nepal Living Standard Survey. Central Bureau of Statistics, Nepal.

CBS, 2007. Four Monthly statistical Bulletin vol I 2064. Central Bureau of Statistics, Nepal.

MOAC/WFP/FAO, 2007. Crop assessment mission report, 2006/07. Ministry of Agriculture and Cooperative, World Food Program and Food and Agriculture Organization, Nepal. 
MOAC, 2007. Statistical Information on Nepalese Agriculture 2006/7. Ministry of Agriculture and Cooperative, Nepal.

www.cbs.gov.np

www.fao.org

www. moac.gov.np

www.nrb. org. np

\section{ANNEXES}

Annex 1: National urban consumer price index $(1995 / 96=100)$ mid-February 2008 (Magh 2064)

\begin{tabular}{l|c|c|c|c}
\hline Groups and Sub-Groups & Weight\% & J an. 2007 & J an. 2008 & The changes \% \\
\hline 1. OVERALL INDEX & 100 & 184.5 & 196.3 & 6.4 \\
1.1. FOOD and BEVERAGES & 53.2 & 175.5 & 189.3 & 7.9 \\
Grains and Cereal Products & 18.0 & 173.7 & 197.1 & 13.5 \\
$\quad$ Rice and Rice Products & 14.16 & 164.2 & 193.0 & 17.5 \\
Pulses & 2.73 & 171.2 & 194.1 & 13.4 \\
Vegetables and Fruits & 7.89 & 152.2 & 144.7 & -4.9 \\
Spices & 1.85 & 186.8 & 185.6 & -0.6 \\
Meat, Fish and Eggs & 5.21 & 185.2 & 197.1 & 6.4 \\
Milk and Milk Products & 4.05 & 170.2 & 181.4 & 6.6 \\
Oil and Ghee & 3.07 & 158.0 & 187.7 & 18.8 \\
Sugar and Related Products & 1.21 & 150.1 & 134.0 & -10.7 \\
Beverages & 2.28 & 188.7 & 192.7 & 2.1 \\
Restaurant Meals & 6.91 & 210.4 & 225.8 & 7.3 \\
\hline \multicolumn{2}{|c}{}
\end{tabular}

